\title{
Effect of pyrene on denitrification activity and abundance and composition of denitrifying community in an agricultural soil
}

\author{
Guang-Xia Guo ${ }^{a}$, Huan Deng ${ }^{a}$, Min Qiao ${ }^{a}$, Yu-Jing Mu ${ }^{a}$, Yong-Guan Zhu ${ }^{\text {a,b,* }}$ \\ a State Key Lab of Regional and Urban Ecology, Research Center for Eco-Environmental Sciences, Chinese Academy of Sciences, Beijing 100085, China \\ ${ }^{\mathrm{b}}$ Key Lab of Urban Environment and Health, Institute of Urban Environment, Chinese Academy of Sciences, Xiamen 361021, China
}

\section{A R T I C L E I N F O}

\section{Article history:}

Received 25 October 2010

Received in revised form

18 March 2011

Accepted 19 March 2011

\section{Keywords:}

Denitrifiers

$\mathrm{EC}_{50}$

Phylogenetic analysis

Temporal shifts

Diversity

\begin{abstract}
A B S T R A C T
Toxicity of pyrene on the denitrifiers was studied by spiking an agricultural soil with pyrene to a series of concentrations $\left(0-500 \mathrm{mg} \mathrm{kg}^{-1}\right)$ followed by dose-response and dynamic incubation experiments. Results showed a positive correlation between potential denitrification activity and copy numbers of denitrifying functional genes (nirK, nirS and nosZ), and were both negatively correlated with pyrene concentrations. Based on the comparison of $\mathrm{EC}_{50}$ values, denitrifiers harboring nirK, nirS or nos $Z$ gene were more sensitive than denitrification activity, and denitrifiers harboring nirS gene were more sensitive than that harboring nirK or nosZ genes. Seven days after spiking with $\mathrm{EC}_{50}$ concentration of pyrene, denitrifiers diversity decreased and community composition changed in comparison with the control. Phylogenetic analyses of three genes showed that the addition of pyrene increased the proportion of Bradyrhizobiaceae, Rhodospirillales, Burkholderiales and Pseudomonadales. Some species belonging to these groups were reported to be able to degrade PAHs.
\end{abstract}

(c) 2011 Elsevier Ltd. All rights reserved.

\section{Introduction}

Polycyclic aromatic hydrocarbons (PAHs) have been identified as carcinogenic, mutagenic, and teratogenic (Perera, 1997). As a result, the US Environmental Protection Agency (US EPA) and the European Community placed PAHs in the priority pollutant list (Wild and Jones, 1995). Unfortunately, PAHs pollutant streams that enter the environment have not been sufficiently stemmed; indeed their intensity continues to increase, mainly due to the rising demand for fossil fuels (Conte et al., 2001). Being both chemically very stable while exhibiting a high hydrophobicity ensures that PAHs are effectively adsorbed onto soil particles and in particular soil organic matter (Means et al., 1980). With the continued build-up of PAHs in soil, the resulting impacts on soil ecosystem health are of great concern, with several studies having been carried out to evaluate the toxic effects of PAHs on dehydrogenase and urease activities, soil respiration (Miles and Doucette, 2001; Klimkowicz-Pawlas and MaliszewskaKordybach, 2003) and soil bacteria in relation to nitrogen (N) cycle (e.g. nitrifying bacteria) (Maliszewska-Kordybach et al., 2007).

Denitrification is a crucial microbial process in the $\mathrm{N}$ cycle in which oxidized $\mathrm{N}$ compounds $\left(\mathrm{NO}_{3}{ }^{-}, \mathrm{NO}_{2}{ }^{-}\right)$are reduced into

\footnotetext{
* Corresponding author.

E-mail address: ygzhu@rcees.ac.cn (Y.-G. Zhu).
}

gaseous products $\left(\mathrm{NO}, \mathrm{N}_{2} \mathrm{O}\right.$, and $\mathrm{N}_{2}$ ). $\mathrm{N}_{2} \mathrm{O}$ is the potent greenhouse gas that can cause ozone depletion in the stratosphere. Soils are considered to be the major source of $\mathrm{N}_{2} \mathrm{O}$ emission contributing $65 \%$ of the total global emission, with $6.0 \mathrm{Tg} \mathrm{N}_{2} \mathrm{O}-\mathrm{N} \mathrm{yr}^{-1}$ from natural soils and $4.2 \mathrm{Tg} \mathrm{N}_{2} \mathrm{O}-\mathrm{N} \mathrm{yr}^{-1}$ from agricultural soils (Intergovernmental Panel on Climate Change, 2001). Studies have shown that denitrifying communities are affected by soil conditions including temperature, moisture, $\mathrm{pH}$ and substrate (e.g. $\mathrm{NO}_{3}{ }^{-}$, organic carbon) concentration (Braker et al., 2010; Henderson et al., 2010; Liu et al., 2010; Stres et al., 2008; Lalisse-Grundmann et al., 1988; Renner and Becker, 1970). High exposures to metals such as cadmium, copper, zinc and silver can also be detrimental to denitrifying communities (Holtan-Hartwig et al., 2002; McKenney and Vriesacker, 1985; Throbäck et al., 2007). In addition, the selective inhibition of different steps in the denitrification process in soil could aggravate the ecological consequences of pollution. It has been shown that the reduction of $\mathrm{NO}_{2}{ }^{-}$appeared to be more sensitive than the reduction of $\mathrm{NO}_{3}{ }^{-}$ (Bollag and Barabasz, 1979; McKenney and Vriesacker, 1985), which would result in the accumulation of $\mathrm{NO}_{2}{ }^{-}$to toxic levels, and a selective inhibition of $\mathrm{NO}$ reductase or $\mathrm{N}_{2} \mathrm{O}$ reductase by heavy metals enhanced $\mathrm{NO}$ or $\mathrm{N}_{2} \mathrm{O}$ emission from soils (HoltanHartwig et al., 2002). With the increase of PAHs in soil, ecotoxicity of PAHs on denitrification in soil deserves more attention. It is therefore of ecological significance to understand the responses of denitrifying communities and their functions in different phases of 
denitrification processes in soil to PAHs stress, and to identify sensitive and resistant organisms.

A complete denitrification process involves a nitrate reductase encoded by the narG, narH or napA gene, a nitrite reductase encoded by the nirK or nirS gene, a nitric oxide reductase encoded by the qnorB or $\operatorname{cnor} B$ gene and a nitrous oxide reductase encoded by the nosZ gene. Most denitrifiers belong to a wide range of subclasses of Proteobacteria, while there are still some closely related to Archaea, halophilic and hyperthermophilic branches as well as mitochondria of certain fungi (Zumft, 1997). The common difference between true denitrifiers and other microorganisms with nitrate-reducing ability is that the true denitrifiers have either a copper-containing enzyme encoded by nirK or a cytochrome cd1 enzyme encoded by nirS (Braker et al., 2000; Zumft, 1997). Therefore, the nirK and nirS genes have frequently been used as gene markers to analyze denitrifying community. Although some denitrifiers lack this nitrous oxide reductase enzyme, the nos $Z$ gene could be used as a target for different populations of the denitrifying bacteria capable of nitrous oxide reduction (Throbäck et al., 2004). Since not all denitrifiers have the complete suite of denitrification enzymes (Zumft, 1997), two or more functional genes are often used as molecular markers for this microbial group. In most studies, the analyses of the molecular ecology of the denitrifying community were based on nirK, nirS and nosZ genes (Braker et al., 2000; Throbäck et al., 2004). The activity of reductases and the expression of functional genes involved in denitrification process varies among individual strains (Zumft, 1997), and community composition is thus considered to be able to influence functionality at both community and ecosystem levels (Braker et al., 2010). Nevertheless, some studies have reported correlations between abundance and function as well as between structure and function of denitrifying communities (Bremer et al., 2009; Hallin et al., 2009; Rich et al., 2003) while others not (Dandie et al., 2008; Miller et al., 2008; Wertz et al., 2009). Therefore, it is important to determine the correlations among changes in function, abundance and composition of the denitrifying community in an agricultural soil in response to PAHs stress.

The objective of this study was therefore to assess the toxicity of pyrene on denitrification activity and the abundance, diversity and composition of the denitrifying community. In order to make comprehensive assessment, acute toxicity and dynamic toxicity were tested. The acute toxicity was determined through a doseresponse test of denitrification activity and abundance of denitrifiers against pyrene. The dynamic toxicity was determined during a 7-day course after pyrene perturbation by measuring $\mathrm{N}_{2} \mathrm{O}$ accumulation and reduction as well as the diversity and community composition of the denitrifiers.

\section{Material and methods}

\subsection{Soil sampling and characteristics}

The soil sample was collected from the surface $(0-20 \mathrm{~cm}$ in depth) of an agricultural field located in Beiye Chang $\left(39^{\circ} 44^{\prime} \mathrm{N}, 116^{\circ} 25^{\prime} \mathrm{E}\right)$, Daxing district, Beijing, in September 2008. Brassica rapa pekinensis, Raphanus sativus and Brassica oleracea var. botrytis were grown in this field. This field has been regularly fertilized with organic manure and ammonium nitrate for more than twenty years. After visible thick roots and leaves were removed, the fresh soil sample was passed through a $2 \mathrm{~mm}$ sievemesh, and then stored at $4{ }^{\circ} \mathrm{C}$ until further experiments were conducted. Part of the soil sample was air-dried and passed through a $0.45 \mathrm{~mm}$ sieve for chemical analyses.

Soil pH was determined by a pH meter (FE20, METTLER TOLEDO, Switzerland) at a soil: water ratio of $1: 2.5(\mathrm{w} / \mathrm{v})$. Nitrate and ammonium were determined by an automated Continuous Flow Analyzer (SAN++, SKALAR, Netherlands). Total organic carbon was determined by Element Analyzer (Vario EL III, Elementar, USA). We measured 16 PAHs which were listed as priority pollutants by US EPA in triplicate by GC-MS (6890N/5975C, Agilent, USA) according to EPA method 8270. Characteristics of the soil sample were as follows: $\mathrm{pH}, 7.69 ; \mathrm{NO}_{3}{ }^{-}-\mathrm{N}, 384 \mathrm{mg} \mathrm{kg}^{-1} ; \mathrm{NH}_{4}{ }^{+}-\mathrm{N}$, $772 \mathrm{mg} \mathrm{kg}^{-1}$; organic carbon, $19.9 \mathrm{~g} \mathrm{~kg}^{-1}$; pyrene, $59.7 \mu \mathrm{g} \mathrm{kg}^{-1} ; \sum \mathrm{PAHs}, 1.03 \mathrm{mg} \mathrm{kg}^{-1}$

\subsection{Spiking of soil with pyrene}

Crystalline pyrene (L08162, Alfa Aesar, Lancaster, USA) was dissolved in acetone and uniformly sprayed onto soil to produce sub-samples with pyrene levels of 0 (pyrene-free, with acetone only), 20, 50, 100, 200, 400, 700, 1000, 2000 and $5000 \mathrm{mg} \mathrm{kg}^{-1}$ dry weight soil (Brinch et al., 2002; Peng et al., 2010). These subsamples were homogenized by continuous hand shaking in $1000 \mathrm{~mL}$ glass bottles and the bottles were closed for $5 \mathrm{~min}$ to let the solvent disperse, followed by storage at $25{ }^{\circ} \mathrm{C}$ in the dark for $16 \mathrm{~h}$. When acetone was evaporated off, sub-samples were mixed with non-spiked soil at the ratio of 1:9 and shaken thoroughly, generating final pyrene levels of 0 (non-spiked control), 2, 5, 10, 20, 40, 70, 100, 200 and $500 \mathrm{mg} \mathrm{kg}^{-1}$ dry weight soil (denoted as Pr2, Pr5, Pr10, Pr20, Pr40, Pr70, Pr100, Pr200 and Pr500, respectively). The pyrene-spiked samples were continuously shaked by hand to ensure homogeneous distribution of pyrene in the soil. Triplicate samples of each treatment were collected and stored at $-80^{\circ} \mathrm{C}$ for DNA extraction and quantitative PCR, and other used for acute and dynamic incubation experiments.

\subsection{Potential denitrification activity}

Potential denitrification activity (PDA) was determined by using the acetylene $\left(\mathrm{C}_{2} \mathrm{H}_{2}\right)$ inhibition technique (Smith and Tiedje, 1979; Schinner et al., 1996). In this study, we modified the method by omitting any extra nitrate and carbon since the content of $\mathrm{NO}_{3}{ }^{-}-\mathrm{N}$ and organic carbon was already high $\left(384 \mathrm{mg} \mathrm{kg}^{-1}\right.$ and $19.9 \mathrm{~g} \mathrm{~kg}^{-1}$, respectively) due to excessive fertilization. It was reported that the optimum concentrations for $\mathrm{NO}_{3}{ }^{-}-\mathrm{N}$ should not exceed $50 \mathrm{mg} \mathrm{kg} \mathrm{ge}^{-1}$, and an excess of $\mathrm{NO}_{3}{ }^{-}-\mathrm{N}$ ( $>100 \mathrm{mg} \mathrm{kg}^{-1}$ dry soil) might inhibit $\mathrm{N}_{2} \mathrm{O}$ production (LalisseGrundmann et al., 1988; Renner and Becker, 1970).

Quadruplicates of pyrene-spiked soil (15 g fresh soil) were weighed into $120-\mathrm{mL}$ serum bottles capped with butyl rubber stoppers. The moistures of all spiked samples were adjusted to $50 \%$ (w/w, absolute water content) with deionized water to make nitrate dissolve in water and thereby generating anaerobic conditions. All spiked samples were made anoxic by four cycles of evacuation and filling with $\mathrm{N}_{2}$ (1.5 atm), while shaken continuously and thoroughly. A final over-pressure in the bottles was released by piercing a $0.5 \mathrm{~mm}$ (inner diameter) needle through the rubber septum. To avoid $\mathrm{O}_{2}$ to enter during this venting, the needle was mounted on a $5 \mathrm{~mL}$ plastic syringe (without piston) filled with $1 \mathrm{~mL}$ distilled water. Then $\mathrm{C}_{2} \mathrm{H}_{2}$ was added to the headspace (injection and subsequent release of over-pressure, final concentration $10 \% \mathrm{v} / \mathrm{v}$ ) to inhibit $\mathrm{N}_{2} \mathrm{O}$ reduction. All bottles were incubated at $25^{\circ} \mathrm{C}$ in the dark for $24 \mathrm{~h}$. Gas samples $(1 \mathrm{~mL})$ were withdrawn from bottles by glass precision gas syringes and were injected into $\mathrm{N}_{2}$-filled ( $\left.1 \mathrm{~atm}\right) 29.0 \mathrm{~mL}$ vials capped with butyl rubber septa. These diluted gas samples were then analyzed for $\mathrm{N}_{2} \mathrm{O}$ by a gas chromatograph (SP3410, Beijing Analytical Instrument Factory) connected to an ECD detector as described previously by Pang et al. (2009), and the amount of $\mathrm{N}_{2} \mathrm{O}$ in the headspace and PDA were calculated as indicated by Schinner et al. (1996).

\subsection{Time-course of $\mathrm{N}_{2} \mathrm{O}$ accumulation and reduction}

Dynamics of $\mathrm{N}_{2} \mathrm{O}$ accumulation and reduction were determined by anaerobic incubation with and without $\mathrm{C}_{2} \mathrm{H}_{2}$ (Yoshinari et al., 1977). Non-spiked control soil and soil treated with $\mathrm{EC}_{50}$ concentration of pyrene (concentration of pyrene in soil causing 50\% inhibition of denitrification activity; denoted as EC50 treatment) were prepared for the dynamic experiment. Fifteen grams of soil (fresh weight) was transferred to a $120-\mathrm{mL}$ serum bottle capped with butyl rubber stoppers, with eight replicates for each treatment. Soil moisture, oxygen-exhaust and soil incubation conditions were as the same as for the PDA experiment. Four of eight replicates in each treatment were randomly selected and injected with $10 \% \mathrm{C}_{2} \mathrm{H}_{2}$ (final concentration $10 \% \mathrm{v} / \mathrm{v}$ ) to inhibit the $\mathrm{N}_{2} \mathrm{O}$ reduction. The moment of the injection of $\mathrm{C}_{2} \mathrm{H}_{2}$ was regarded as the start of incubation. All bottles were then incubated at $25^{\circ} \mathrm{C}$ in the dark for 7 days. The $\mathrm{N}_{2} \mathrm{O}$ concentration of each replicate was analyzed at intervals of $24 \mathrm{~h}$. Triplicate soil samples of each treatment (control and EC50, without $\mathrm{C}_{2} \mathrm{H}_{2}$ ) were collected at the end of incubation (on the 7th day) and stored at $-80^{\circ} \mathrm{C}$ before DNA extraction.

\subsection{DNA extraction}

The DNA was extracted from $0.5 \mathrm{~g}$ soil (stored at $-80^{\circ} \mathrm{C}$ ) with the Fast DNA SPIN kit for soil (BIO101) following the manufacturer's instructions. The recovered DNA was eluted in $10 \mathrm{mM}$ Tris- $\mathrm{HCl}$ buffer ( $\mathrm{pH} 7.5$ ). The purity and the quantity of the DNA were determined by UV-Vis Spectrophotometer (ND-1000, NanoDrop, USA) at 260 and $280 \mathrm{~nm}$. 260/280 ratios were found to be all above 1.8. The DNA solution was stored at $-20^{\circ} \mathrm{C}$.

The DNA extraction of the soils spiked with $0-500 \mathrm{mg} \mathrm{kg}^{-1}$ of pyrene were destined to real-time quantitative PCR, and DNA from the EC50 experiment to clone libraries of functional genes.

\subsection{Real-time quantitative $P C R$}

Quantification of nirK, nirS and nosZ genes was performed on a iCycler iQ ${ }^{\mathrm{TM}} 5$ Thermocycler (BioRad, USA). The $25-\mu \mathrm{L}$ reaction mixtures contained $12.5 \mu \mathrm{L}$ of SYBR 
Green Premix ExTaq(TaKaRa, Japan), $0.5 \mu \mathrm{L}$ of each $20 \mu \mathrm{M}$ primer, $0.25 \mu \mathrm{L} 25 \mathrm{mM}$ BSA and $1 \mu \mathrm{L}$ of template DNA. Thermal cycling conditions for nirK and nirS genes were as follows: pre-incubation at $94^{\circ} \mathrm{C}$ for $2 \mathrm{~min}, 40$ cycles consisting of denaturation at $94{ }^{\circ} \mathrm{C}$ for $30 \mathrm{~s}$, annealing at $58^{\circ} \mathrm{C}$ for $40 \mathrm{~s}$, extension at $72^{\circ} \mathrm{C}$ for $30 \mathrm{~s}$, and fluorescence was read during each cycle at $83^{\circ} \mathrm{C}$ for $10 \mathrm{~s}$, followed by melting curve analysis at $58-94{ }^{\circ} \mathrm{C}\left(0.5^{\circ} \mathrm{C}\right.$ per reading $), 10$-s hold. Thermal cycling conditions for nos $Z$ gene were similar to that of nirK and nirS genes except for the annealing temperature starting at $58^{\circ} \mathrm{C}$ for the initial 5 cycles with touchdown of $-1{ }^{\circ} \mathrm{C}$ by cycle followed by $53{ }^{\circ} \mathrm{C}$ for 35 cycles, and melting curve analysis at $53-94{ }^{\circ} \mathrm{C}\left(0.5^{\circ} \mathrm{C}\right.$ per reading $)$.

The standard curves for the quantitative PCR were established using nirK, nirS and nos $Z$ gene fragments cloned into plasmid pGEM-T Easy Vector (3015 bp, Promega, Madison, USA). nirK, nirS and nosZ gene fragments were amplified with the primer pairs 1F and 5R (Braker et al., 1998), R3cd and cd3aF (Michotey et al., 2000), Z-F and 1622R (Throbäck et al., 2004), respectively. The amplicons were gel-purified using the Gel Clean-up System (Promega, Madison, USA) and cloned using the pGEM-T Easy cloning kit according to the manufacturer's instructions. Plasmids were transformed into Escherichia coli JM109 competent cells. Plasmid DNA was extracted using a Qiagen Plasmid Mini Kit (Qiagen Nordic) and plasmid concentration was determined by using a NanoDrop ND-1000 spectrophotometer. Plasmid DNA was diluted in ten-fold series to generate standard curves. All quantitative PCR reactions including unknown samples and standard curves were performed in triplicate and no template control (NTC) treatments were included in all runs.

\subsection{Cloning, sequencing and phylogenetic analysis}

For the construction of a clone library, DNA extracts from three replicated soil samples were mixed and served as the template of PCR. Three primer sets $(1 F / 5 R$, $\mathrm{R} 3 \mathrm{Cd} / \mathrm{cd} 3 \mathrm{aF}, \mathrm{Z}-\mathrm{F} / 1622 \mathrm{R}$ ) as described in above were used in the PCR amplification of nirK, nirS and nosZ gene fragments. The $25-\mu \mathrm{L}$ reaction mixtures contained $1 \mu \mathrm{L}$ of template DNA, $0.5 \mu \mathrm{L}$ of each $20 \mu \mathrm{M}$ primer, $2.5 \mu \mathrm{L}$ of $10 \times$ buffer $\left(\mathrm{Mg}^{2+}\right.$ plus $), 2 \mu \mathrm{L}$ of $10 \mathrm{mM}$ dNTPs mixture ( $2.5 \mathrm{mM}$ of each), $0.25 \mu \mathrm{L}$ of $25 \mathrm{mM}$ bovine serum albumin (BSA), and 1.25 units of Taq DNA polymerase (Takara). Thermal cycling conditions were the same as those of quantitative PCR. PCR products of the correct size were purified and then ligated to pGEM-T Easy Vector and transformed into Escherichia coli JM109 competent cells. The bacteria were transferred into LB agar (containing ampicillin, X-Gal and IPTG) plates. After incubation overnight at $37^{\circ} \mathrm{C}$, white colonies (putative positive clones) were picked as correct inserts. More than fifty white clones were selected for each treatment. In total, three separate clone libraries (NirK clone library, NirS clone library and NosZ clone library) were constructed for control and EC50 treatments, respectively. The insert size in each clone was examined by vector-targeted PCR (primers T7 and SP6). The clones with correct insert size were used for sequencing analyses in SinoGenoMax Co., Ltd (Beijing, China).

Vector and primer sequences were removed using DNASTAR Lasergene 7.1. The gene fragment sequences were compared with available sequences in the GenBank database using the NCBI BIASTx program (http://ncbi.nlm.nih.gov/blast). Reference sequences were retrieved from NCBI FefSeq and GenBank. These retrieved nucleotide sequences were aligned with reference sequences using MEGA4 (Tamura et al., 2007). Phylogenetic analysis was performed using a neighbor-joining algorithm and distance calculation by MEGA4. Sequences that were $95 \%$ or more identical were considered as a unique operational taxonomic unit (OTU) (Katuyama et al., 2008).

The nucleotide sequences of nirS, nirK and nosZ gene fragments determined in this study were submitted in GenBank database under the following accession numbers: nirK, HQ221373-HQ221409; nirS, HQ221410-HQ221435; and nosZ, HQ221436-HQ221463.

\subsection{Data analyses}

Ecotoxicity of pyrene for denitrification was described by $\mathrm{EC}_{50}$ values which were calculated on the basis of Logistic functions regression models assessing the relationships of pyrene concentration-PDA and pyrene concentration-copy numbers of nirK, nirS and nosZ genes by using SigmaPlot5 (Jandel Corporation, CA, USA) (Throbäck et al., 2007) and were expressed in milligrams of pyrene per kilogram of dry soil. The amounts of nirK, nirS, and nosZ in the soil were calculated on an oven-dry weight $\left(105^{\circ} \mathrm{C}\right)$ basis.

Diversity indices, Shannon-Weiner $\left(H^{\prime}\right)$, and Simpson's Reciprocal (1/D) were calculated by using the following formulas: $H^{\prime}=-\sum\left(p_{i}\right)\left(\log _{2} p_{i}\right), \mathrm{D}=1 /\left(1-\sum p_{i}{ }^{2}\right)$. Here, $p i$ is the proportion of clones in OTU $i$ relative to the total clone numbers (Yoshida et al., 2009).

One-way ANOVA was performed to determine significant variations at the level of $P<0.05$ by using SPSS (11.0).

\section{Results}

\subsection{Potential denitrification activity}

Potential denitrification activity (PDA) was expressed in terms of $\mathrm{N}_{2} \mathrm{O}$ concentration in the serum bottle headspace (Fig. 1). PDA

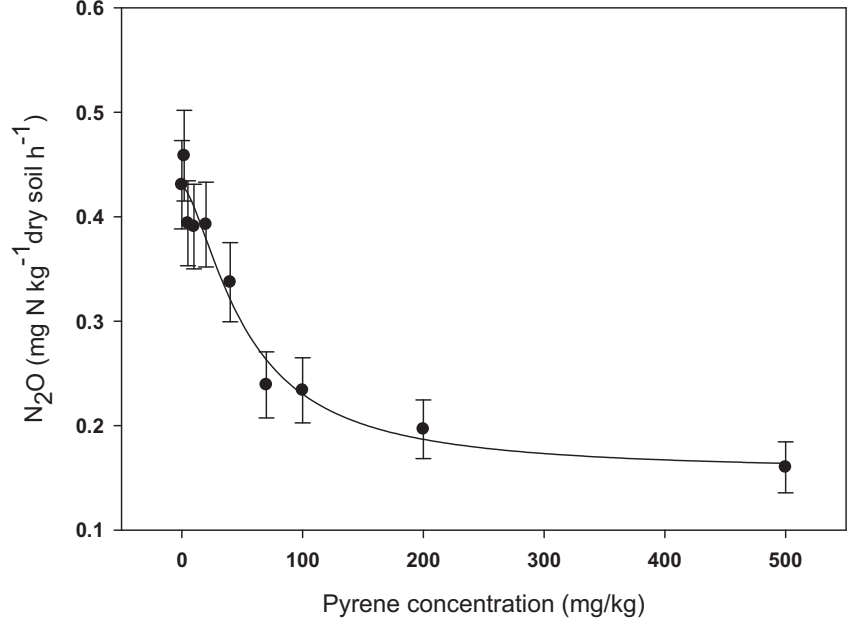

Fig. 1. Potential denitrification activity ( $P D A$, presented as $\mathrm{mg} \mathrm{N} \mathrm{kg}^{-1} \mathrm{dry}$ soil h${ }^{-1}$ ) under different pyrene concentrations. The data are means of quadruplicate measurements. Bars represent standard deviation. The fitting curve and the mean $\mathrm{EC}_{50}$ value (59.74 $\mathrm{mg} \mathrm{kg}^{-1}$ ) were obtained by applying "Four Parameter Logistic Curve" $\left(\mathrm{y}=\min +(\max -\min ) /\left(1+\left(\mathrm{x} / \mathrm{EC}_{50}\right)^{\text {Hillslope }}\right)\right)\left(r^{2}=0.97, P<0.0001\right)$ to the relation of pyrene concentration and $P D A$.

decreased with increasing pyrene concentrations, and was the lowest $\left(0.16 \mathrm{mg} \mathrm{N} \mathrm{kg}^{-1} \mathrm{~h}^{-1}\right)$ in the Pr500 treatment. PDA in spiked soil was not significantly lower than the control until pyrene concentration was as high as $70 \mathrm{mg} \mathrm{kg}^{-1}$. The mean $\mathrm{EC}_{50}$ value of pyrene for $P D A$ was $59.7 \mathrm{mg} \mathrm{kg}^{-1}\left(r^{2}=0.97, P<0.0001\right)$.

\subsection{Dynamics of $\mathrm{N}_{2} \mathrm{O}$ accumulation and reduction}

One day after pyrene perturbation, $\mathrm{N}_{2} \mathrm{O}$ accumulation (NA) and $\mathrm{N}_{2} \mathrm{O}$ reduction rate (NR) in the EC50 treatment were $213 \%$ and $55.5 \%$ of those in the control treatment (Fig. 2). However, NA of the EC50 treatment increased to $438 \%$ times of the control treatment on the 4 th day and then decreased to $162 \%$ of the control treatment on the 7th day. NR of the EC50 treatment increased to $96.3 \%$ of the control treatment on the 3rd day. From the 3rd day to the 7th day, NRs of the two treatments were comparatively stable, and the ratio of NR of the EC50 treatment to that of the control treatment fluctuated within the range of 96.3-98.6\%. Meanwhile, the soil pyrene

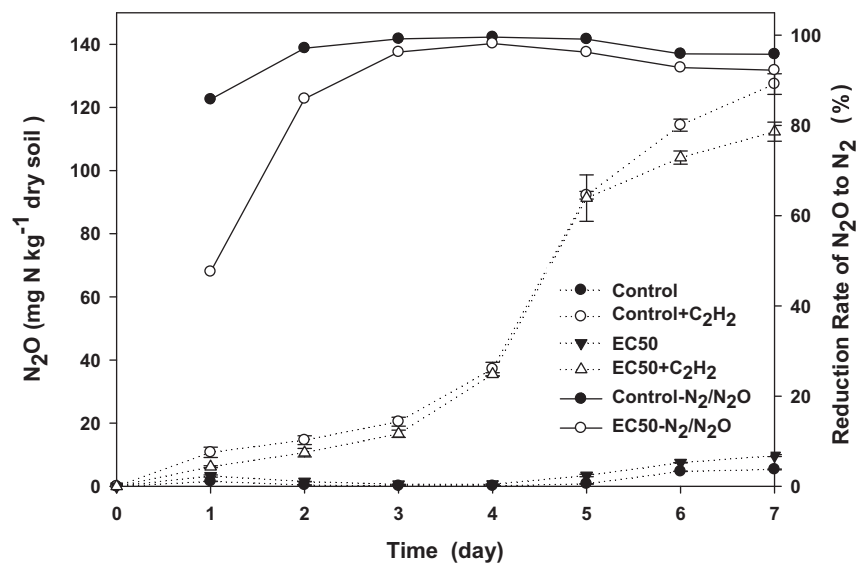

Fig. 2. Time-course of $\mathrm{N}_{2} \mathrm{O}$ production and $\mathrm{N}_{2} \mathrm{O}$ reduction ratio (reduced $\mathrm{N}_{2} \mathrm{O}$ /tota $\mathrm{N}_{2} \mathrm{O}$ ) of the control and EC50 treatments with and without $10 \% \mathrm{C}_{2} \mathrm{H}_{2}$ during anaerobic incubation. The data are means of quadruplicate measurements. Bars represent standard deviation. 
concentration of the EC50 treatment declined from $59.7 \mathrm{mg} \mathrm{kg}^{-1}$ on the 1 st day to $33.4 \mathrm{mg} \mathrm{kg}^{-1}$ on the 7 th day.

\subsection{Abundance of nirK, nirS and nosZ genes}

The copy numbers of nirK, nirS and nosZ genes in response to pyrene concentrations are shown in Fig. 3. The copy numbers of nirK gene (around $10^{7}$ ) in the control and spiked treatments were an order of magnitude lower than those of the nirS and nos $Z$ genes (around $10^{8}$ ) in respective treatments. The copy numbers of the three genes generally decreased with the increase of pyrene concentrations with the exception that the copy numbers of nirK gene in the $\operatorname{Pr} 2\left(4.40 \times 10^{7}\right.$ copies $g^{-1}$ dry soil $)$, $\operatorname{Pr} 10\left(4.24 \times 10^{7}\right.$ copies $\mathrm{g}^{-1}$ dry soil $)$ and $\operatorname{Pr} 20\left(4.02 \times 10^{7}\right.$ copies $^{-1}$ dry soil $)$ treatments were significantly higher than the non-spiked control $\left(3.66 \times 10^{7}\right.$ copies $g^{-1}$ dry soil). The $\mathrm{EC}_{50}$ values of pyrene for copy numbers of nirK, nirS and nosZ genes were 39.3, 17.7 and $31.5 \mathrm{mg} \mathrm{kg}^{-1}\left(r^{2}>0.85\right.$ and $P<0.01$, figures not shown), respectively. The linear regression $\left(r^{2}>0.74, P<0.01\right)$ showed that $P D A$ was positively correlated with copy numbers of the three genes (Fig. 4).

\subsection{Diversity of the denitrifying community}

Diversity of the denitrifying community was evaluated by Shannon-Weiner index and Simpson's Reciprocal index based on NirK, NirS and NosZ clone libraries in the control and EC50 treatments (Table 1). A total of 93 clones and 37 OTUs for nirK gene, 89 clones and 26 OTUs for nirS gene as well as 97 clones and 31 OTUs for nosZ gene were obtained from the control and the EC50 treatments. Both Shannon index and Simpson index of the three genes in the control treatment were higher than in the EC50 treatment.

\subsection{Phylogenetic trees of nirk, nirS and nosZ genes}

Phylogenetic trees based on the NirK, NirS and NosZ nucleic acid sequences ( $480 \mathrm{bp}, 371-386 \mathrm{bp}$ and $387-420 \mathrm{bp}$, respectively) are shown in Figs. 5-7, respectively. The clones of the three genes obtained in this study spread throughout the trees and affiliated to Proteobacteria. The phylogenetic tree of the nirK gene was divided into five major clusters (cluster I-IV). The clones belonging to clusters I, II and III were closely related to Rhizobiaceae, Bradyrhizobiaceae

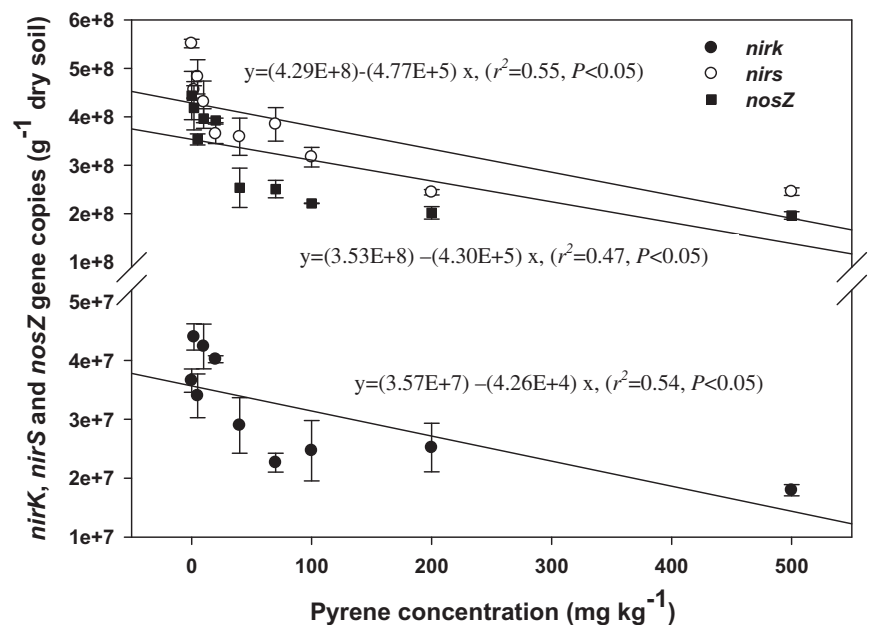

Fig. 3. The copy numbers of the nirK, nirS and nosZ genes in non-spiked control and spiked treatments (Pr2-Pr500). The quantitative PCR was run in triplicate for each treatment, and average values and the standard deviations are shown.

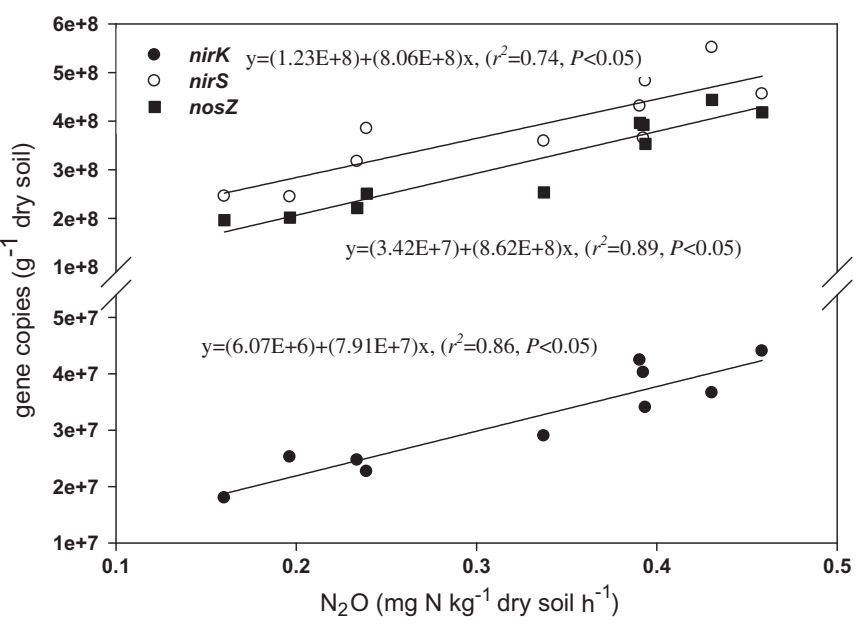

Fig. 4. The copy numbers of the nirK, nirS and nosZ genes in non-spiked control and spiked treatments (Pr2-Pr500). The copy numbers are expressed relative to denitrification activity.

and Phyllobacteriaceae, respectively, affiliated to Alphaproteobacteria. The clones belonging to IV were closely related to Alcaligenaceae, affiliated to Betaproteobacteria.

The NirS tree was divided into six clusters (cluster I-VI). The NirS clones in clusters II and III were primarily related to NirS of Rhodobacteraceae and Bradyrhizobiaceae, respectively, affiliated to Alphaproteobacteria. The NirS clones in cluster IV were relatively closely related to NirS of Rhodocyclaceae, affiliated to Betaproteobacteria; NirS clones in cluster V were relatively closely related to NirS of Pseudomonadaceae, affiliated to Gammaproteobacteria, while those in clusters I and cluster VI were relatively distantly related to NirS of known denitrifying bacteria. BLAST homology search also showed that the clone sequences in clusters I and VI did not match NirS from any denitrifiers isolates, although some of them showed high similarities to uncultured deduced NirS clones from environmental samples.

The NosZ tree was divided into seven clusters (cluster I-VII). NosZ clones in clusters I, II, III and IV were relatively closely related to NosZ of Brucellaceae, Rhizobiaceae, Bradyrhizobiaceae and Rhodospirillaceae, respectively, belonging to Alphaproteobacteria. NosZ clones in clusters V, VI and VII were closely related to NosZ of Alcaligenaceae, Burkholderiaceae and Oxalobacteraceae, respectively, belonging to Betaproteobacteria.

\subsection{Shifts of NirK, NirS and NosZ diversities}

Relative abundance of NirK, NirS and NosZ clones of the EC50 treatment was different from that of the control treatment (Fig. 8).

Table 1

Diversity indices of nirK, nirS and nosZ clones in the control and EC50 treatments.

\begin{tabular}{llllll}
\hline $\begin{array}{l}\text { Gene } \\
\text { Name of } \\
\text { treatments }\end{array}$ & $\begin{array}{l}\text { No. of } \\
\text { clones }\end{array}$ & $\begin{array}{l}\text { No. of OTUs cut) } \\
(5 \%\end{array}$ & $\begin{array}{l}\text { Shannon-Wiener } \\
\text { Index }\left(H^{\prime}\right)\end{array}$ & $\begin{array}{l}\text { Simpson's Reciprocal } \\
\text { Index }(1 / \mathrm{D})\end{array}$ \\
\hline nirK & Control & 46 & 22 & 2.78 & 15.92 \\
& EC50 & 47 & 21 & 2.62 & 11.88 \\
& Total & 93 & 37 & - & - \\
nirS & Control & 47 & 22 & 2.75 & 14.04 \\
& EC50 & 41 & 15 & 2.4 & 10.65 \\
& Total & 88 & 26 & - & - \\
nosZ & Control & 48 & 18 & 2.51 & 10.07 \\
& EC50 & 49 & 18 & 2.26 & 5.88 \\
& Total & 97 & 31 & - & - \\
\hline
\end{tabular}




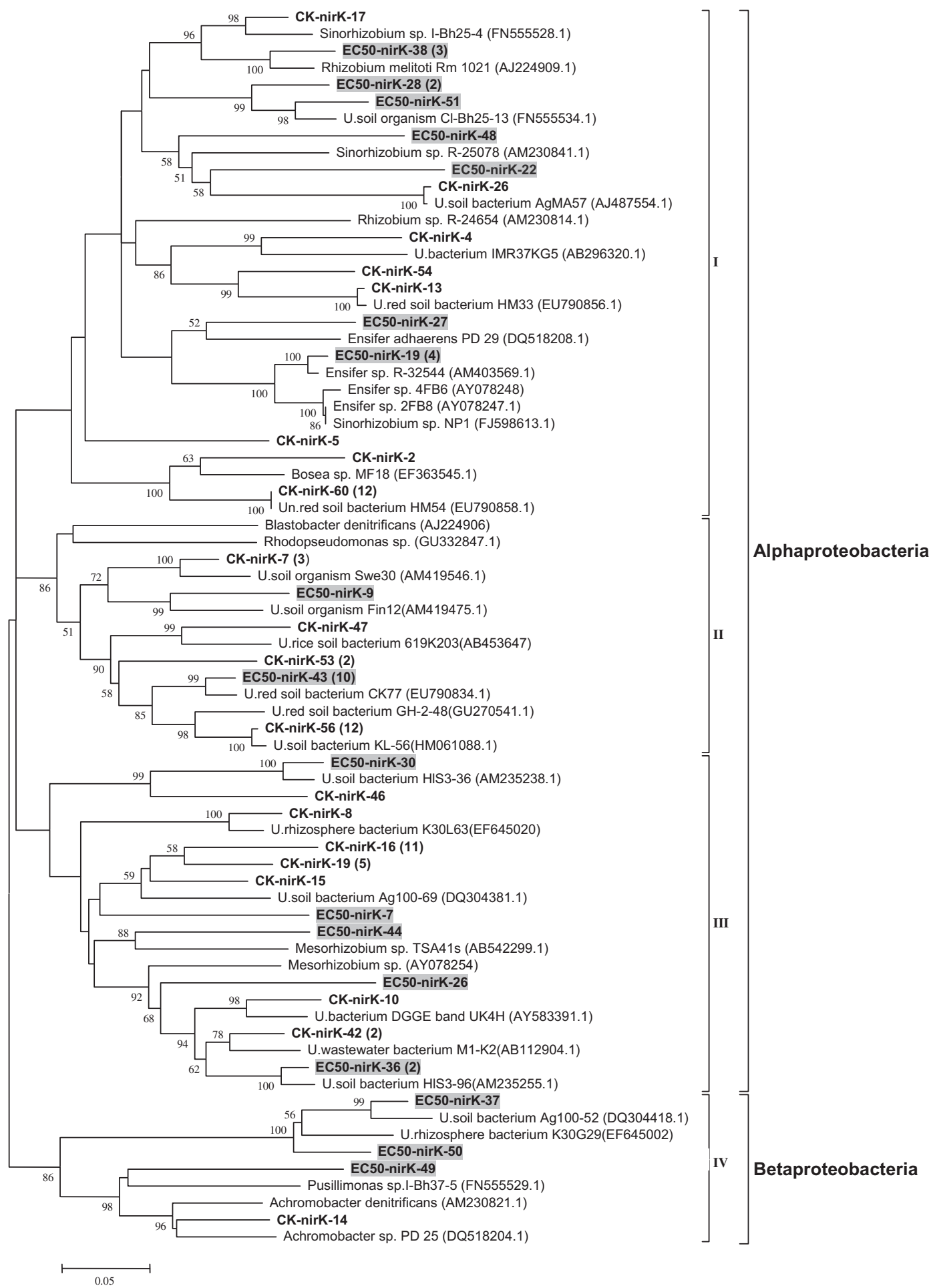

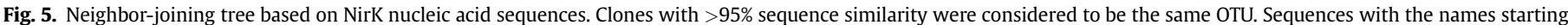

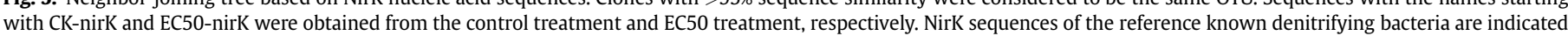

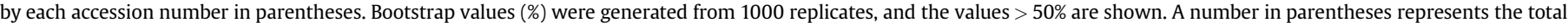
number of clones in each OTU.

In the EC50 treatment, the proportions of the NirK clones belonging to cluster I and cluster III decreased by $12.6 \%$ and $4.95 \%$, respectively, compared to the control treatment, while those belonging to clusters II and IV related to Bradyrhizobiaceae and Alcaligenaceae increased by $14.4 \%$ and $4.21 \%$, respectively.
The proportions of the NirS clones belonging to clusters II, III and VI decreased by $12.1 \%, 1.82 \%$ and $3.63 \%$, respectively, compared with the control treatment. The NirS clones belonging to cluster IV related to Rhodocyclaceae were detected in the control treatment but not in the EC50 treatment. A notable change 

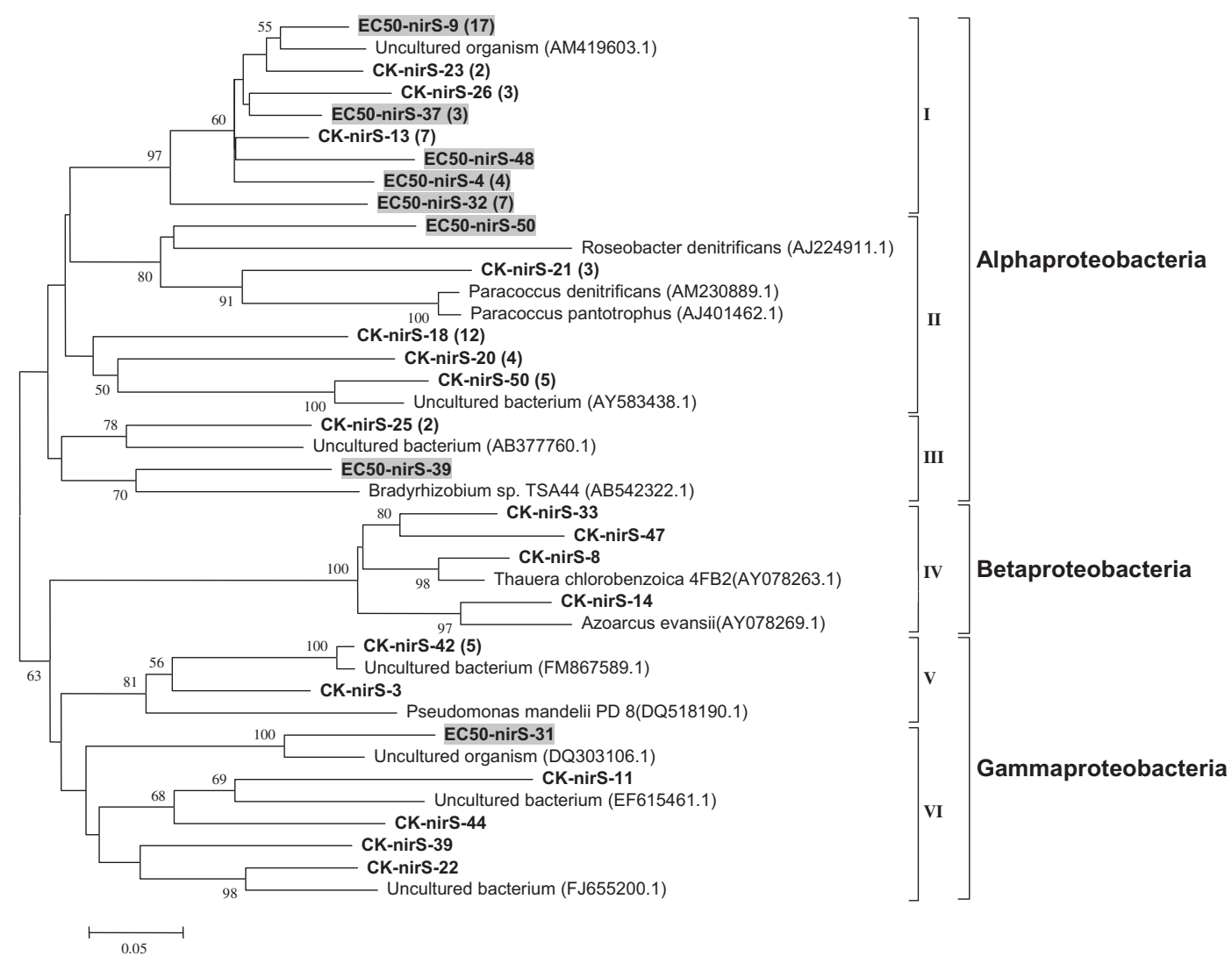

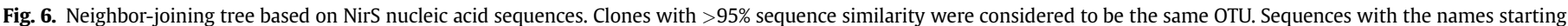

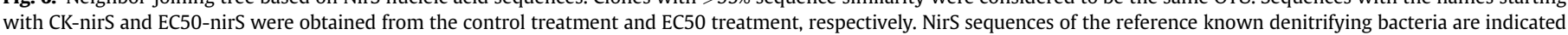

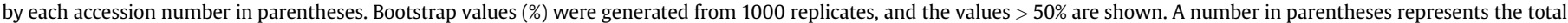
number of clones in each OTU.

was that the proportion of the clones belonging to cluster I (unknown branch) increased $25.1 \%$ in the EC50 treatment. In addition, the proportion of the NirS clones related to Pseudomonadaceae slightly increased with the addition of pyrene.

In the EC50 treatment, the proportion of NosZ clones belonging to the cluster I decreased by $4.29 \%$, while those belonging to cluster IV related to Rhodospirillaceae increased by $2.00 \%$, and those belonging to V and VII affiliated to Burkholderiales increased by $2.95 \%$, compared to the control treatment, respectively. The NosZ clones in cluster III related to Bradyrhizobiaceae which were detected in the control treatment but not in the EC50 treatment.

\section{Discussion}

\subsection{Potential denitrification activity and dynamic of $\mathrm{N}_{2} \mathrm{O}$}

Our results showed that $P D A$ generally decreased with increasing pyrene concentrations. This was consistent with the results obtained by Contreras-Ramos et al. (2009) that the addition of PAHs to the sludge-amended soil reduced the $\mathrm{N}_{2} \mathrm{O}$ emission rate. Maliszewska-Kordybach et al. (2007) tested EC $_{50}$ values of phenanthrene for nitrification potential in 50 different soils and found that the $\mathrm{EC}_{50}$ values were within the range of $146-1670 \mathrm{mg} \mathrm{kg}^{-1}$. In our study, the mean $\mathrm{EC}_{50}$ value of pyrene for $P D A$ was lower than this range. The lower $\mathrm{EC}_{50}$ of pyrene than phenanthrene could be mostly attributed to the fact that the toxicity of phenanthrene with three benzene rings was lower than that of pyrene with four benzene rings and that phenanthrene was easier to be degraded than pyrene.
In the time-course experiment, the $\mathrm{N}_{2} \mathrm{O}$ accumulation of the EC50 treatment was higher than that of the control treatment. Holtan-Hartwig et al. (2002) also found that $\mathrm{N}_{2} \mathrm{O}$ accumulated to a higher level in the heavy metal-spiked soil than in the nonspiked soil. This was likely because $\mathrm{N}_{2} \mathrm{O}$ reductase was inhibited more readily by pyrene than NO reductase and the selective inhibition resulted in the accumulation of $\mathrm{N}_{2} \mathrm{O}$ (Holtan-Hartwig et al., 2002). The $\mathrm{N}_{2} \mathrm{O}$ accumulation and $\mathrm{N}_{2} \mathrm{O}$ reduction in the EC50 treatment gradually diminished, and was close to the level of the control treatment during the 7-day incubation. Meanwhile, pyrene concentration of the EC50 treatment declined during the 7-day incubation. Previous studies showed that PAHs could be degraded under denitrifying conditions by using nitrate as electron acceptors, a mechanism named co-metabolism (Ambrosoli et al., 2005; Coates et al., 1997; McNally et al., 1998; Rockne and Strand, 2001; Rockne et al., 2000). Pollutant degradation and transformation to more volatile or less toxic forms were commonly used strategies for bacteria to reduce the toxicity of their immediate surroundings (Ford, 1993). In our study, most of denitrifiers were closely related to the orders of Rhizobiales, Rhodobacterales, Burkholderiales and Pseudomonadales through phylogenetic analyses, and it has been reported that some species in these orders (Keum et al., 2006; Johnson et al., 2004; Zhang et al., 2004; Guo et al., 2008; Balashova et al., 1999), and a great number of other bacterial and fungal species in soil (Haritash and Kaushik, 2009) could degrade PAHs through cometabolism. Degradation as well as aging of PAHs could alleviate stress and promote the recovery of denitrification enzyme activity (Maliszewska-Kordybach, 2005). 

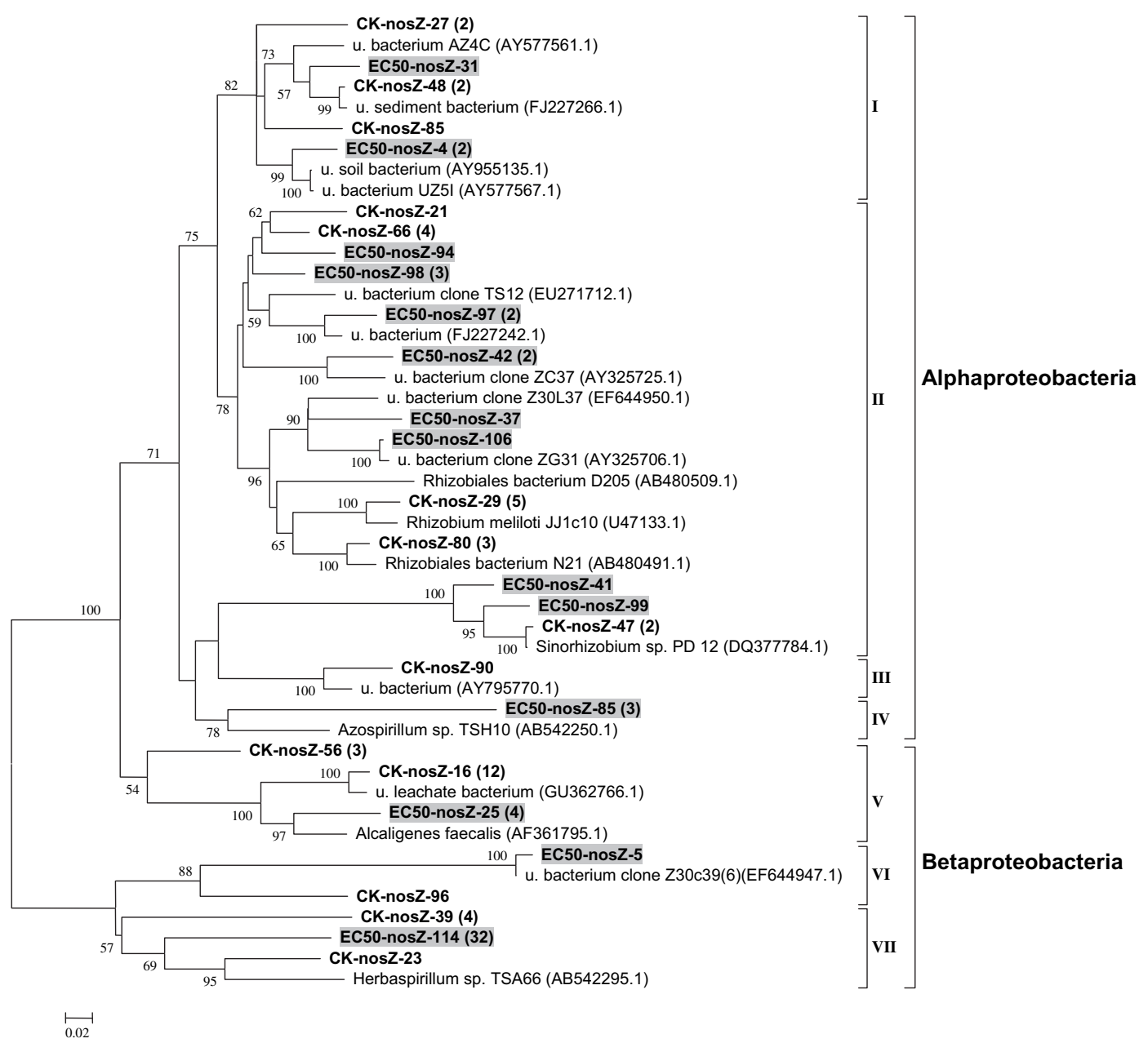

Fig. 7. Neighbor-joining tree based on NosZ nucleic acid sequences. Clones with $>95 \%$ sequence similarity were considered to be the same OTU. Sequences with the names starting with CK-nosZ and EC50-nosZ were obtained from the control treatment and EC50 treatment, respectively. NosZ sequences of the reference known denitrifying bacteria are indicated by each accession number in parentheses. Bootstrap values (\%) were generated from 1000 replicates, and the values $>50 \%$ are shown. A number in parentheses represents the total number of clones in each OTU.

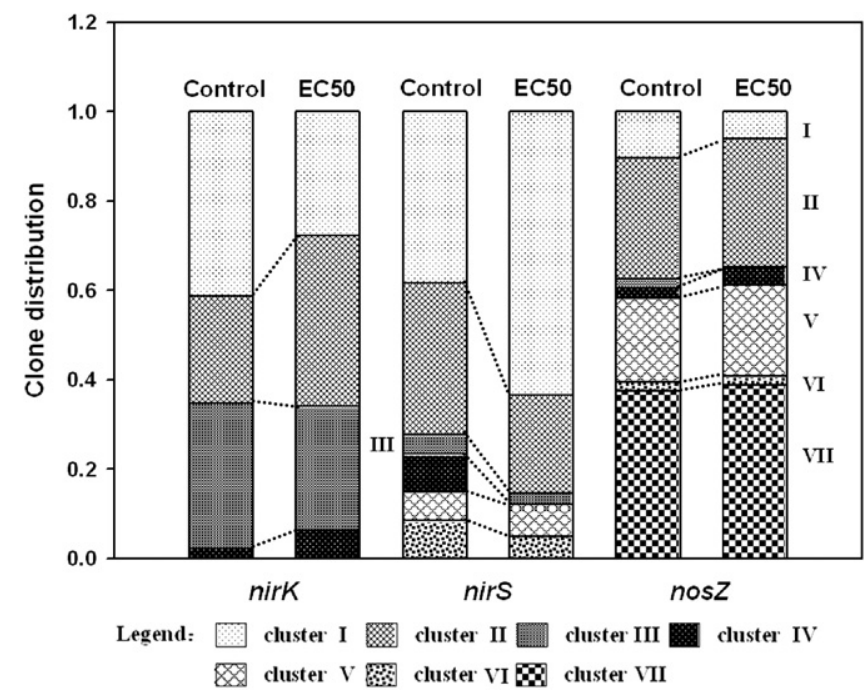

Fig. 8. Temporal shifts in NirK, NirS and NosZ clone distributions. NirK, NirS and NosZ clones were grouped into four, six and seven clusters, respectively.

\subsection{Abundance of the denitrifying community}

Our results showed that the copy numbers of the nirK gene were around $10^{7}$, while those of nirS and nosZ genes were as high as $10^{8}$, indicating that nirS and nos $Z$ genes were dominant in the present agricultural soil. Some studies, however, showed much lower copy numbers $\left(10^{6}\right)$ for the nirS gene and similar copy numbers for the nirK gene $\left(10^{7}\right)$ in paddy soil (Yoshida et al., 2009, 2010). The niche differentiation or abundance difference in the nirS- and nirK-type denitrifiers depended on the habitat selection (Enwall et al., 2010) and nutrient concentration. The nirS population was more adapted to soils with comparatively high concentrations of organic nutrients (Cole et al., 2004) and $\mathrm{NO}_{3}{ }^{-}-\mathrm{N}$ (Bárta et al., 2010). Due to fertilization, the present soil was high in organic carbon $\left(19.9 \mathrm{~g} \mathrm{~kg}^{-1}\right)$ and in $\mathrm{NO}_{3}{ }^{-}-\mathrm{N}\left(384 \mathrm{mg} \mathrm{kg}^{-1}\right)$, and high soil fertility might be responsible for the high copy numbers of the nirS gene.

Our study clearly showed that PDA was positively related to the copy numbers of nirK, nirS and nosZ genes, and high concentration of pyrene addition decreased both PDA and the abundance of denitrifers harboring the three genes. Previous studies showed that denitrification enzyme activity was correlated with the copy numbers of nirK gene (Throbäck et al., 2007) and nosZ gene (Hallin et al., 2009), suggesting that denitrifiers harboring these functional genes played an important role in the denitrification process, and 
the abundance of the denitrifying community could predict the corresponding process (Hallin et al., 2009).

The mean $\mathrm{EC}_{50}$ values of pyrene for copy numbers of nirK, nirS and nos $Z$ genes were lower than that of pyrene for $P D A$, indicating that denitrifiers harboring nirK, nirS or nosZ gene was more sensitive to pyrene than PDA, and denitrifiers harboring nirS gene was more sensitive to pyrene than that harboring nirK or nosZ gene. Previous studies suggested that soil microorganisms, being in intimate contact with the soil environment, could be considered as the best indicators of soil pollution because they might be responsive to contaminants and react rapidly to soil perturbation (Maliszewska-Kordybach et al., 2007). Considering that nirK and nirS genes carry out nitric oxide reduction process whereas nosZ gene implements nitrous oxide reduction, our study further demonstrated that microbial functions and abundance of microorganisms carrying out different denitrification processes were different in sensitivity to pyrene contamination.

\subsection{Shifts in diversity and composition \\ of the denitrifying community}

In our study, both Shannon index and Simpson index of nirK, nirS and nosZ genes decreased with the addition of pyrene, indicating that pyrene reduced denitrifiers diversity. It has been reported that the addition of heavy metals or organic pollutants could decrease microbial diversity (Shannon index and richness) (Bamborough and Cummings, 2009; Kozdrój and van Elsas, 2001). The two diversity indices for nirK gene in our study were similar to those reported in forest soils and a paddy soil (Katuyama et al., 2008; Yoshida et al., 2009), and those of nosZ gene were similar to those reported in meadow and turfgrass soil (Dell et al., 2010; Stres et al., 2004; Zhang et al., 2006). However, the diversity indices for nirS gene in our study were lower than those in a flooded paddy field reported by Yoshida et al. (2009). There are substantial evidences that the diversity and composition of soil bacterial communities can be influenced by a wide range of biotic and abiotic factors including vegetation, trophic status, salinity, soil pH and heavy metals (McArthur et al., 1988; Lefranc et al., 2005; Lozupone and Knight, 2007; Fierer and Jackson, 2006; Gans et al., 2005).

Based on the nirK clone library analysis, the majority of clones from clusters I, II and III were related to Rhizobiales (Rhizobiaceae, Bradyrhizobiaceae and Phyllobacteriaceae), and few clones in cluster IV were related to Burkholderiales (Alcaligenaceae), similar to the previous studies (Bremer et al., 2007; Saito et al., 2008; Yoshida et al., 2009). However, this did not mean that these nirKharboring denitrifiers belonged to Rhizobiales or Burkholderiales, since the nirK phylogeny was incompatible with the 16S rDNA phylogeny (Heylen et al., 2006; Jones et al., 2008; Philippot et al., 2002; Yoshida et al., 2009). Our results showed that over $80 \%$ of NirS clones distributed in clusters I and VI (unknown branch), cluster II (Rhodobacterales). The NirS clones in clusters I and VI were distantly related to known denitrifiers, and some of our clones in the two clusters were dissimilar to the uncultured NirS clone sequences (e.g. AM419603.1 and EF615461.1), indicating that they were unique to our soil. However, Saito et al. (2008) reported that NirS clones related to Burkholderiales and Rhodocyclales dominated in the rice paddy soil (Saito et al., 2008). A possible reason was that plant communities or the rhizosphere and soil factors could affect the structure and activity of the denitrifying community (Kowalchuk et al., 2002; Philippot et al., 2002). Based on the nosZ clone library analysis, the overwhelming majority of clones (cluster I-III, and cluster V-VII) were related to Rhizobiales (Brucellaceae, Rhizobiaceae and Bradyrhizobiaceae) and Burkholderiales (Alcaligenaceae, Burkholderiaceae and Oxalobacteraceae) and only few clones in cluster IV were related to Rhodospirillales (Rhodospirillaceae), and the NosZ-based denitrifiers composition from our studied soil was similar to that from other farmland soils (Enwall et al., 2005; Horn et al., 2006).

Our study clearly demonstrated the temporal shifts in community composition of the nirS-, nirK- and nosZ-harboring denitrifiers in soil after the addition of pyrene. Previous studies also showed that ammonium, fertilization, plant species, sampling time, water logging and temperature all temporarily altered the structure of nirK-harboring denitrifying community (Avrahami et al., 2002; Braker et al., 2010; Bremer et al., 2007; Wolsing and Priemé, 2004; Yoshida et al., 2009). The genetic shifts of the denitrifying community due to PAHs perturbation could be attributed to the inhibition of sensitive and the development of tolerant species (Leahy and Colwell, 1990; Ford, 1993; Whittaker, 1975). In our study, the development of tolerant species could be reflected by the higher proportion of Bradyrhizobiaceae, Rhodospirillales, Burkholderiales and Pseudomonadales in the EC50 treatment, and it has been reported that Afipia broomeae, Burkholderia sp. DBT1, Achromobacter sp. NCW, Thalassopira xianhensis sp. nov. and Pseudomonas putida belonging to the above four groups were isolated from contaminated soils, wastewater, sludge and marine, and these species were able to degrade PAHs and other hydrocarbons (Bodour et al., 2003; Guo et al., 2008; Zhao et al., 2010; Balashova et al., 1999).

\section{Conclusion}

Our results clearly showed that pyrene reduced denitrification activity as well as the abundance, diversity and composition of the denitrifying community. The abundance of the denitrifying community harboring nirK, nirS or nosZ gene is more sensitive to pyrene than potential denitrification activity. Our study further demonstrated that the abundance of denitrifiers carrying out different processes were different in sensitivity to pyrene. Pyrene addition increased the proportions of four groups including Bradyrhizobiaceae, Rhodospirillales, Burkholderiales and Pseudomonadales, with each containing some species that can degrade PAHs.

\section{Acknowledgements}

This study was financially supported by the Chinese Academy of Sciences (KZCX1-YW-06-03) and the Ministry of Science and Technology, China (2007CB407301). The authors would like to thank Dr Paul Williams for proofreading the manuscript.

\section{References}

Ambrosoli, R., Petruzzelli, L., Minati, J.L., Marsan, F.A., 2005. Anaerobic PAH degradation in soil by a mixed bacterial consortium under denitrifying conditions. Chemosphere 60, 1231-1236.

Avrahami, S Conrad, R. Braker, G., 2002. Effect of soil ammonium concentration on $\mathrm{N}_{2} \mathrm{O}$ release and on the community structure of ammonia oxidizers and denitrifiers. Applied and Environmental Microbiology 68, 5685-5692.

Balashova, N.V., Kosheleva, I.A., Golovchenko, N.P., Boronin, A.M., 1999. Phenanthrene metabolism by Pseudomonas and Burkholderia strains. Process Biochemistry 35, 291-296.

Bamborough, L., Cummings, S.P., 2009. The impact of increasing heavy metal stress on the diversity and structure of the bacterial and actinobacterial communities of metallophytic grassland soil. Biology and Fertility of Soils 45, 273-280.

Bárta, J., Tahovská, K., Kaňa, J., Šantrưčková, H., 2010. The effect of nitrate addition on abundance of nirK, nirS and gln genes in acidified Norway spruce forest soil. Geophysical Research Abstracts 12, 10333.

Bodour, A.A., Wang, J.M., Brusseau, M.L., Maier, R.M., 2003. Temporal change in culturable phenanthrene degraders in response to long-term exposure to phenanthrene in a soil column system. Environmental Microbiology 5, 888-895.

Bollag, J.M., Barabasz, W., 1979. Effect of heavy metals on the denitrification process in soil. Journal of Environmental Quality 8, 196-201. 
Braker, G., Schwarz, J., Conrad, R., 2010. Influence of temperature on the composition and activity of denitrifying soil communities. FEMS Microbiology Ecology $73,134-148$.

Braker, G., Zhou, J., Wu, L., Devol, A.H., Tiedje, J.M., 2000. Nitrite reductase genes (nirK and nirS) as functional markers to investigate diversity of denitrifying bacteria in pacific northwest marine sediment communities. Applied and Environmental Microbiology 66, 2096-2104.

Braker, G., Fesefeldt, A., Witzel, K.P., 1998. Development of PCR primer systems for amplification of nitrite reductase genes (nirK and nirS) to detect denitrifying bacteria in environmental samples. Applied and Environmental Microbiology $64,3769-3775$

Bremer, C., Braker, G., Matthies, D., Reuter, A., Engels, C., Conrad, R., 2007. Impact of plant functional group, plant species, and sampling time on the composition of nirK-type denitrifier communities in soil. Applied and Environmental Microbiology 73, 6876-6884.

Bremer, C., Braker, G., Matthies, D., Beierkuhnlein, C., Conrad, R., 2009. Plant presence and species combination, but not diversity, influence denitrifier activity and the composition of nirK-type denitrifier communities in grassland soil. FEMS Microbiology Ecology 70, 377-387.

Brinch, U.C., Ekelund, F., Jacobsen, C.S., 2002. Method for spiking soil samples with organic compounds. Applied and Environmental Microbiology 68, 1808-1816.

Coates, J.D., Woodward, J., Allen, J., Philp, P., Lovley, D.R., 1997. Anaerobic degradation of polycyclic aromatic hydrocarbons and alkanes in petroleum-contaminated marine harbor sediments. Applied and Environmental Microbiology 63, 3589-3593.

Cole, A.C., Semmens, M.J., Lapara, T.M., 2004. Stratification of activity and bacterial community structure in biofilms grown on membranes transferring oxygen. Applied and Environmental Microbiology 70, 1982-1989.

Conte, P., Zena, A., Pilidis, G., Piccolo, A., 2001. Increased retention of polycyclic aromatic hydrocarbons in soils induced by soil treatment with humic substances. Environmental Pollution 112, 27-31.

Contreras-Ramos, S.M., Alvarez-Bernal, D., Montes-Molina, J.A., Cleemput, O.V., Dendooven, L., 2009. Emission of nitrous oxide from hydrocarbon contaminated soil amended with waste water sludge and earthworms. Applied Soil Ecology $41,69-76$.

Dandie, C.E., Burton, D.L., Zebarth, B.J., Henderson, S.L., Trevors, J.T., Goyer, C., 2008. Changes in bacterial denitrifier community abundance over time in an agricultural field and their relationship with denitrification activity. Applied and Environmental Microbiology 74, 5997-6005.

Dell, E.A., Bowman, D., Rufty, T., Shi, W., 2010. The community composition of soildenitrifying bacteria from a turfgrass environment. Research in Microbiology $161,315-325$.

Enwall, K., Philippot, L., Hallin, S., 2005. Activity and composition of the denitrifying bacterial community respond differently to long-term fertilization. Applied and Environmental Microbiology 71, 8335-8343.

Enwall, K., Throbäck, I.N., Stenberg, M., Söderström, M., Hallin, S., 2010. Soil resources influence spatial patterns of denitrifying communities at scales compatible with land management. Applied and Environmental Microbiology 76, 2243-2250.

Fierer, N., Jackson, R.B., 2006. The diversity and biogeography of soil bacterial communities. Proceedings of the National Academy of Sciences of the United States of America 103, 626-631.

Ford, T., 1993. Pollutant effects on the microbial ecosystem. In Napa Conference on Genetic and Molecular Ecotoxicology in Yountville, California.

Gans, J., Wolinsky, M., Dunbar, J., 2005. Computational improvements reveal great bacterial diversity and high metal toxicity in soil. Science 309, 1387-1390.

Guo, W., Li, D., Tao, Y., Gao, P., Hu, J., 2008. Isolation and description of a stable carbazole-degrading microbial consortium consisting of Chryseobacterium sp. NCY and Achromobacter sp. NCW. Current Microbiology 57, 251-257.

Hallin, S., Jones, C.M., Schloter, M., Philippot, L., 2009. Relationship between Ncycling communities and ecosystem functioning in a 50-year-old fertilization experiment. The ISME Journal 3, 597-605.

Haritash, A.K., Kaushik, C.P., 2009. Biodegradation aspects of polycyclic aromatic hydrocarbons (PAHs): a review. Journal of Hazardous Materials 169, 1-15.

Henderson, S.L., Dandie, C.E., Patten, C.L., Zebarth, B.J., Burton, D.L., Trevors, J.T., Goyer, C., 2010. Changes in denitrifier abundance, denitrification gene mRNA levels, nitrous oxide emissions, and denitrification in anoxic soil microcosms amended with glucose and plant residues. Applied and Environmental Microbiology 76, 2155-2164.

Heylen, K., Gevers, D., Vanparys, B., Wittebolle, L., Geets, J., Boon, N., Vos, P.D., 2006. The incidence of nirS and nirK and their genetic heterogeneity in cultivated denitrifiers. Environmental Microbiology 8, 2012-2021.

Holtan-Hartwig, L., Bechmann, M., Høyås, T.R., Linjordet, R., Bakken, L.R., 2002. Heavy metals tolerance of soil denitrifying communities: $\mathrm{N}_{2} \mathrm{O}$ dynamics. Soil Biology \& Biochemistry 34, 1181-1190.

Horn, M.A., Drake, H.L., Schramm, A., 2006. Nitrous oxide reductase genes (nosZ) of denitrifying microbial populations in soil and the earthworm gut are phylogenetically similar. Applied and Environmental Microbiology 72, 1019-1026.

Inter governmental Panel on Climate Change, 2001. Climate Change 2001: the Scientific Basis. Contribution of working group I to the third assessment report of the intergovernmental panel on climate change. In: Houghton, J.T., Ding, Y., Griggs, D.J., Noguer, M., van der Linden, P.J., Dai, X., Maskell, K., Johnson, C.A. (Eds.). Cambridge University Press, Cambridge.

Jones, C.M., Stres, B., Rosenquist, M., Hallin, S., 2008. Phylogenetic analysis of nitrite, nitric oxide, and nitrous oxide respiratory enzymes reveal a complex evolutionary history for denitrification. Molecular Biology and Evolution 25, 1955-1966.

Johnson, D.L., Maguire, K.L., Anderson, D.R., McGrath, S.P., 2004. Enhanced dissipation of chrysene in planted soil: the impact of a rhizobial inoculums. Soil Biology \& Biochemistry 36, 33-38.

Katuyama, C., Kondo, N., Suwa, Y., Yamagishi, T., Itoh, M., Ohte, N., Kimura, H. Nagaosa, K., Kato, K., 2008. Denitrification activity and relevant bacteria revealed by nitrite reductase gene fragments in soil of temperate mixed forest. Microbes and Environments 23, 337-345.

Keum, Y.S., Seo, J.S., Hu, Y.T., Li, Q.X., 2006. Degradation pathways of phenanthrene by Sinorhizobium sp. C4. Applied Microbiology Biotechnology 71, 935-941.

Klimkowicz-Pawlas, A., Maliszewska-Kordybach, B., 2003. Effect of anthracene and pyrene on dehydrogenases activity in soils exposed and unexposed to PAHs. Water, Air, \& Soil Pollution 145, 169-186.

Kowalchuk, G.A., Buma, D.S., de Boer, W., Klinkhamer, P.G., van Veen, J.A., 2002. Effects of above-ground plant species composition and diversity on the diversity of soil-borne microorganisms. Antonie van Leeuwenhoek 81 $509-520$

Kozdrój, J., van Elsas, J.D., 2001. Structural diversity of microorganisms in chemically perturbed soil assessed by molecular and cytochemical approaches. Journal of Microbiological Methods 43, 197-212.

Lalisse-Grundmann, G., Brunel, B., Chalamet, A., 1988. Denitrification in a cultivated soil: optimal glucose and nitrate concentrations. Soil Biology \& Biochemistry 20, 839-844.

Leahy, J.G., Colwell, R.R., 1990. Microbial degradation of hydrocarbons in the environment. Microbiological Reviews 54, 305-315.

Lefranc, M., Thenot, A., Lepere, C., Debroas, D., 2005. Genetic diversity of small eukaryotes in lakes differing by their trophic status. Applied and Environmental Microbiology 71, 5935-5942.

Liu, B.B., Mørkved, P.T., Frostegård, Å., Bakken, L.R., 2010. Denitrification gene pools, transcription and kinetics of $\mathrm{NO}, \mathrm{N}_{2} \mathrm{O}$ and $\mathrm{N}_{2}$ production as affected by soil $\mathrm{pH}$. FEMS Microbiology Ecology 72, 407-417.

Lozupone, C.A., Knight, R., 2007. Global patterns in bacterial diversity. Proceedings of the National Academy of Sciences of the United States of America 104 $11436-11440$.

Maliszewska-Kordybach, B., 2005. Dissipation of polycyclic aromatic hydrocarbons in freshly contaminated soils - the effect of soil physicochemical properties and aging. Water, Air, \& Soil Pollution 168, 113-128.

Maliszewska-Kordybach, B., Klimkowicz-Pawlas, A., Smreczak, B., 2007. Ecotoxic effect of phenanthrene on nitrifying bacteria in soils of different properties. Journal of Environmental Quality 36, 1635-1645.

Means, J.C., Wood, S.G., Hassett, J.J., Banwart, W.L., 1980. Sorption of polynuclear aromatic hydrocarbons by sediments and soils. Environmental Science \& Technology 14, 1524-1528.

McArthur, J.V., Kovacic, D.A., Smith, M.H., 1988. Genetic diversity in natural populations of a soil bacterium across a landscape gradient. Proceedings of the National Academy of Sciences of the United States of America 85, 9621-9624

McKenney, D.J., Vriesacker, J.R., 1985. Effect of cadmium contamination on denitrification processes in Brookston clay and Fox sandy loam. Environmenta Pollution 38, 221-233.

McNally, D.L., Mihelcic, J.R., Lueking, D.R., 1998. Biodegradation of three- and fourring polycyclic aromatic hydrocarbons under aerobic and denitrifying conditions. Environmental Science \& Technology 32, 2633-2639.

Michotey, V., Mejean, V., Bonin, P., 2000. Comparison of methods for quantification of cytochrome cd(1)-denitrifying bacteria in environmental marine samples. Applied and Environmental Microbiology 66, 1564-1571.

Miles, R.A., Doucette, W.J., 2001. Assessing the aerobic biodegradability of 14 hydrocarbons in two soils using a simple microcosm/respiration method. Chemosphere 45, 1085-1090.

Miller, M.N., Zebarth, B.J., Dandie, C.E., Burton, D.L., Goyer, C., Trevors, J.T., 2008 Crop residue influence on denitrification, $\mathrm{N}_{2} \mathrm{O}$ emissions and denitrifie community abundance in soil. Soil Biology \& Biochemistry 40, 2553-2562.

Pang, J.Z., Wang, X.K., Mou, Y.J., Ouyang, Z.Y., Liu, W.Z., 2009. Nitrous oxide emissions from an apple orchard soil in the semiarid loess plateau of China. Biology and Fertility of Soils 46 (1), 37-44.

Peng, J.J., Cai, C., Min, O., Li, H., Zhu, Y.G., 2010. Dynamic changes in functional gene copy numbers and microbial communities during degradation of pyrene in soils. Environmental Pollution 158, 2872-2879.

Perera, F.P., 1997. Environment and cancer: who are susceptible? Science 278 1068-1073.

Philippot, L., Piutti, S., Martin-Laurent, F., Hallet, S., Germon, J.C., 2002. Molecular analysis of the nitrate-reducing community from unplanted and maize-planted soils. Applied and Environmental Microbiology 68, 6121-6128.

Rich, J.J., Heichen, R.S., Bottomley, P.J., Cromack, K., Myrold, D.D., 2003. Community composition and functioning of denitrifying bacteria from adjacent meadow and forest soils. Applied and Environmental Microbiology 69, 5974-5982.

Rockne, K.J., Chee-Sanford, J.C., Sanford, R.A., Hedlund, B.P., Staley, J.T., Strand, S.E. 2000. Anaerobic naphthalene degradation by microbial pure cultures under nitrate-reducing conditions. Applied and Environmental Microbiology 66, 1595-1601.

Rockne, K.J., Strand, S.E., 2001. Anaerobic biodegradation of naphthalene, phenanthrene, and biphenyl by a denitrifying enrichment culture. Water Research 35 291-299.

Renner, E.D., Becker, G.E., 1970. Production of nitric oxide and nitrous oxide during denitrification by Corynebacterium nephridii. Journal of Bacteriology 101, 821-826. 
Saito, T., Ishii, S., Otsuka, S., Nishiyama, M., Senoo, K., 2008. Identification of novel betaproteobacteria in a succinate-assimilating population in denitrifying rice paddy soil by using stable isotope probing. Microbes and Environments 23, $192-200$.

Schinner, F., Ohlinger, R., Kandeler, E., Margesin, R. (Eds.), 1996. Methods in Soil Biology. Springer-Verlag, Heidelberg, pp. 151-155. and 179-184.

Smith, S.M., Tiedje, J.M., 1979. Phases of denitrification following oxygen depletion in soil. Soil Biology \& Biochemistry 11, 261-267.

Stres, B., Danevcic, T., Pal, L., Fuka, M.M., Resman, L., Leskovec, S., Hacin, J., Stopar, D. Mahne, I., Mandic-Mulec, I., 2008. Influence of temperature and soil water content on bacterial, archaeal and denitrifying microbial communities in drained fen grassland soil microcosms. FEMS Microbiology Ecology 66, 110-122.

Stres, B., Mahne, I., Avgustin, G., Tiedje, J.M., 2004. Nitrous oxide reductase (nosZ) gene fragments differ between native and cultivated Michigan soils. Applied and Environmental Microbiology 70, 301-309.

Tamura, K., Dudley, J., Nei, M., Kumar, S., 2007. MEGA4: molecular evolutionary genetics analysis (MEGA) software version 4.0. Molecular Biology and Evolution 24, 1596-1599.

Throbäck, I.N., Enwall, K., Jarvis, Å., Hallin, S., 2004. Reassessing PCR primers targeting nirS, nirK and nosZ genes for community surveys of denitrifying bacteria with DGGE. FEMS Microbiology Ecology 49, 401-417.

Throbäck, I.N., Johansson, M., Rosenquist, M., Pell, M., Hansson, M., Hallin, S., 2007. Silver $\left(\mathrm{Ag}^{+}\right)$reduces denitrification and induces enrichment of novel nirK genotypes in soil. FEMS Microbiology Letters 270, 189-194.

Wertz, S., Dandie, C.E., Goyer, C., Trevors, J.T., Patten, C.L., 2009. Diversity of nirK denitrifying genes and transcripts in an agricultural soil. Applied and Environmental Microbiology 75, 7365-7377.

Whittaker, R.H., 1975. Communities and Ecosystems, second ed. Macmillan, New York.
Wild, S.R., Jones, K.C., 1995. Polynuclear aromatic hydrocarbons in the United Kingdom environment: a preliminary source inventory and budget. Environmental Pollution 88, 91-108.

Wolsing, M., Priemé, A., 2004. Observation of high seasonal variation in community structure of denitrifying bacteria in arable soil receiving artificial fertilizer and cattle manure by determining T-RFLP of nir gene fragments. FEMS Microbiology Ecology 48, 261-271.

Yoshinari, T., Hynes, R., Knowles, R., 1977. Acetylene inhibition of nitrous oxide reduction and measurement of denitrification and nitrogen fixation in soil. Soil Biology \& Biochemistry 9, 177-183.

Yoshida, M., Ishii, S., Otsuka, S., Senoo, K., 2009. Temporal shifts in diversity and quantity of nirS and nirK in a rice paddy field soil. Soil Biology \& Biochemistry 41, 2044-2051.

Yoshida, M., Ishii, S., Otsuka, S., Senoo, K., 2010. Nirk-harboring denitrifiers are more responsive to denitrification inducing conditions in rice paddy soil than nirsharboring bacteria. Microbes and Environments 25, 45-48.

Zhang, H., Kallimanis, A., Koukkou, A.I., Drainas, C., 2004. Isolation and characterization of novel bacteria degrading polycyclic aromatic hydrocarbons from polluted Greek soils. Applied Microbiology and Biotechnology 65, 124-131.

Zhang, Y.G., Li, D.Q., Wang, H.M., Xiao, Q.M., Liu, X.D., 2006. The diversity of denitrifying bacteria in the alpine meadow soil of Sanjiangyuan natural reserve in Tibet Plateau. Chinese Science Bulletin 51, 1245-1254.

Zhao, B.S., Wang, H., Li, R.R., Mao, X.W., 2010. Thalassospira xianhensis sp. nov., a polycyclic aromatic hydrocarbon-degrading marine bacterium. International Journal of Systematic and Evolutionary Microbiology 60, 1125-1129.

Zumft, W.G., 1997. Cell biology and molecular basis of denitrification. Microbiology and Molecular Biology Reviews 61, 533-616. 